\title{
Extreme Effects of Season on the Foraging Activities and Colony Productivity of a Stingless Bee (Melipona asilvai Moure, 1971) in Northeast Brazil
}

\author{
Daniela Lima do Nascimento and Fabio Santos Nascimento \\ Departamento de Biologia, Faculdade de Filosofia, Ciências e Letras de Ribeirão Preto, Universidade de São Paulo, \\ 14040-901 Ribeirão Preto, SP, Brazil \\ Correspondence should be addressed to Daniela Lima do Nascimento, daninascimento@usp.br
}

Received 5 March 2012; Revised 13 April 2012; Accepted 15 April 2012

Academic Editor: James Charles Nieh

Copyright ( 2012 D. L. do Nascimento and F. S. Nascimento. This is an open access article distributed under the Creative Commons Attribution License, which permits unrestricted use, distribution, and reproduction in any medium, provided the original work is properly cited.

This study reports the influence of season on foraging activities and internal colonial parameters of Melipona asilvai in an Atlantic forest area of northeast Brazil. We used video cameras connected to a PC to monitor all departures and returns of foragers and the types of materials they carried. Foraging activities decreased almost $90 \%$ from dry to rainy seasons, but temperature and humidity were not the main factors influencing departures. Observed honey storage and an extreme cutback in activities during the rainy period suggest a seasonal diapause in this species.

\section{Introduction}

Foraging activities in social insects are influenced by unpredictable environmental variables in terms of timing and location of food [1]. According to Biesmeijer and de Vries [2], there are two main features which govern foraging activities of bees: (1) internal factors, such as individual memory and threshold response to react to the foraging stimuli, and (2) external factors, such as environmental and colony conditions which determine the level of exposure to stimuli associated with the decision [3-8]. Colonies of honeybees and stingless bees can allocate more foragers to collect nectar and pollen in response to the amount of food in storage and availability of resources in the field [7, 9-12].

Stingless bee colonies consist of several hundred to tens of thousands of individuals, and information exchange among the workers is a key feature to colony foraging efficiency and indirectly to colony growth and reproductive success [13]. The influence of weather on foraging activities has been studied in several eusocial bee species [14-25]. These studies report that weather conditions, light intensity, humidity, food availability, competition, colony state, and physiological conditions of individuals are important factors that influence the foraging activities of Melipona species.

In this study we report an extreme effect on foraging activity and colony production in response to environmental variables for colonies of Melipona asilvai. For this purpose, we used a novel observational approach in order to monitor all daily departures and entrances of foraging bees.

\section{Material and Methods}

2.1. Study Site. The experiments were performed at the Campus of Universidade Federal de Sergipe (UFS), São Cristóvão $\left(10^{\circ} 55^{\prime} \mathrm{S}, 37^{\circ} 03^{\prime} \mathrm{W}\right.$, altitude $\left.2 \mathrm{~m}\right)$. The study area is characterized as a subhumid area of Atlantic Rain Forest or "Zona da Mata." According to Amâncio [26], two distinct seasons are found in this region: a rainy season happening from April to August (pluviosity between $1.100 \mathrm{~mm}$ and $1.500 \mathrm{~mm}$ ) and a dry season taking place from September to March. The air temperature cycle is close to uniform with no significant seasonal thermal variation.

2.2. Species. Three queenright colonies of Melipona asilvai were collected for this study. The colonies, originally from 
Nossa Senhora da Glória, Sergipe state, were transferred to the UFS Entomology Laboratory. Each colony was housed in a wooden box covered with glass to facilitate observation. A plastic tube connected the colonies to the outside environment, thus permitting the bees to forage freely. The temperature in the hives was controlled at $28^{\circ} \mathrm{C}$ by means of a thermostat.

2.3. Data Collection. This study was carried out on March 10-28th 2009 (rainy season) and on June 10-28th 2009 (dry season). We used security microcameras (model CCD Sony 480L Day 0.1 Lux Color) which were placed on small glass-covered boxes $(5.0 \times 3.0 \times 3.0 \mathrm{~cm})$ connected to each entrance tube. Video recordings were programmed to start at 05:00 $\mathrm{h}$, before the first foraging departure, and the recording concluded at 19:00 h, after the termination of outside activities. The cameras were linked to a computer using an AVerMedia EZmaker frame grabber (Avermedia, Milpitas, CA) and VirtualDub software, http://www.virtualdub.org/. This setup allowed the observer to identify the corbiculae load, such as mud (irregular-shaped brown material), resin (brighter rounded material), pollen (whitish to yellowish opaque load), and liquid load (water and nectar). Incoming foragers with liquid presented expanded abdomens compared to other unloaded foragers. Nectar and water loads were not individually determined.

To investigate how seasonality affects food storage and colony conditions, we daily counted honey and pollen pots, brood cells in construction, and the relative number of individuals in the colony (workers on the brood combs). All parameters were registered around 18:00 h after video recording. Data on temperature and relative humidity were measured with a digital thermohygrometer kept outside the laboratory.

2.4. Data Analyses. The data were analysed with a general linear model (GLM) where colonies, season, and time of day were entered into the analysis as the independent variables and number of bees entering or exiting as the dependent variables [27]. The Kruskal-Wallis test and the Mann-Whitney $U$ test were used to verify whether the type of load collected by foragers occurred at distinct periods of the day and to compare colony productivity between seasons, respectively. A Kendau Tau correlation test was also used to estimate the relationship between abiotic factors and the frequency of flights. All analyses were made with Statistica 7.0 (Statsoft inc.).

\section{Results}

3.1. Foraging Activities and Seasonality. General linear mixed models showed that foraging activities were significantly affected by almost all parameters tested (Table 1). Variance between colonies was not significant, meaning that the number of foraging departures and returns between the three colonies were not different. Footage analyses of 73,375 flight returns showed conspicuous differences in activities between rainy and dry seasons. Season, time, and time $x$
TABLE 1: Results of GLM of foraging activities related to dry and rainy seasons, time of day, and studied colonies.

\begin{tabular}{lcccc}
\hline & D.F. & Deviance & $F$ & $P$ \\
\hline Model & 1 & 932658.2 & 320.35 & 0.003 \\
Season & 1 & 805939.7 & 1019.69 & $<0.0001$ \\
Time & 12 & 9770.8 & 12.36 & 0.001 \\
Colony & 2 & 1911.7 & 2.78 & 0.06 \\
Season $*$ time & 12 & 8351.4 & 10.56 & $<0.0001$ \\
Error & 5851 & 790.4 & & \\
\hline
\end{tabular}

season showed significant effects on the frequency of foraging activities.

There was not a strong correlation of air temperature and relative humidity with the frequency of foragers' exiting (Figure 1; dry season: temperature: $\tau=-0.20, P=0.83$ and humidity: $\tau=0.34, P=0.73$; rainy season: temperature: $\tau=2.71, P<0.05$ and humidity: $\tau=-0.03, P=0.37$ ). On the other hand, a comparison of pooled data showed a positive tendency between temperature and number of bees exiting the nest $(\tau=13.94, P<0.001)$.

3.2. Foraging for Resources, Time of Day, and Season. The onset of nest departures during the dry season occurred around $5: 30 \mathrm{~h}$. During the rainy season, the first exiting trips started between 6:00 and 9:00 h, with an exceptional initial foraging exit occurring at 13:00 h. In both seasons, foraging trips ended around 18:00 h. During the dry season, the activity peak of departures occurred between 7:00 and 8:00 h $($ mean \pm S.D. $=38.46 \pm 30.64$ bees; Figure 1(a), while the observations took during the rainy season did not produce a clear peak of activity due to the small number of exiting individuals (Figure 1(b)). Liquid foraging changed in intensity throughout the time of day during the dry season but not in the rainy season where liquid foraging was significantly reduced (dry season: $H_{12}=195.17, P<$ 0.001; rainy season: $H_{12}=104.77, P<0.001$; Figures $3(\mathrm{a})$ and $3(\mathrm{~b})$ ). Foraging for liquid during the dry season began around $6: 00 \mathrm{~h}$, with a peak activity at 7:00 $\mathrm{h}$ (mean \pm S.D $=$ $97.5 \pm 12.4$ bees) and decreased after 11:00 h. A total of 43,228 bees were observed returning with liquid loads. During the rainy season, the activity of liquid collection showed no significant peak (Figure 2(b)). In this period of observations, 1,959 liquid foragers were recorded.

Collection of pollen, resin, and mud also differed among seasons and time of day (Figures 3(a) and 3(b)). Pollen collection showed a significant variation with relation to the time of day in both seasons (dry season: $H_{12}=225.26, P<$ 0.001; rainy season: $H_{12}=66.65, P<0.001$; Figures 2 (a) and 2(b)). 5,198 bees were observed returning with pollen during the dry season and 340 bees during the rainy season. Resin collection peaked at 7:00 $\mathrm{h}$ in the dry season and from 8:00 to $10: 00 \mathrm{~h}$ during the rainy season (dry season: $H_{12}=80.07$, $P<0.001$; rainy season: $\left.H_{12}=32.21, P<0.001\right)$. During the dry and rainy seasons, 6,213 and 118 bees were observed returning with resin, respectively. 


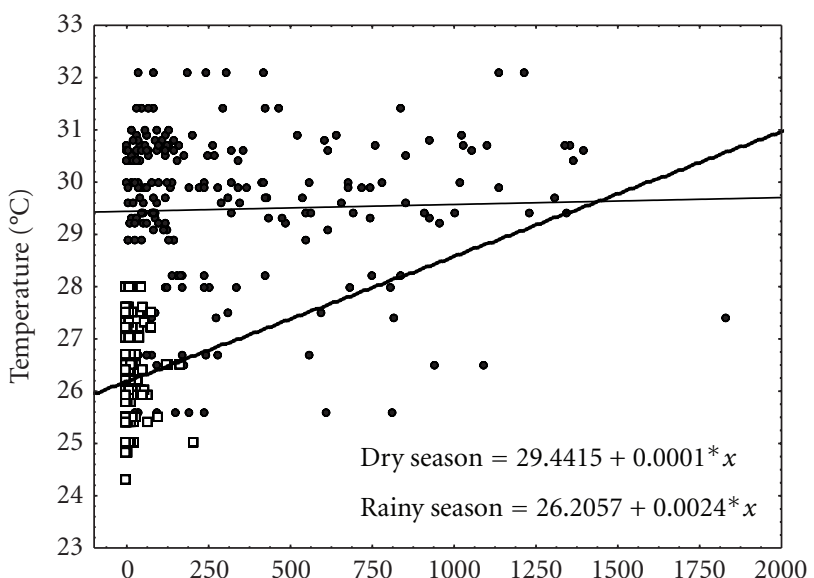

(a)

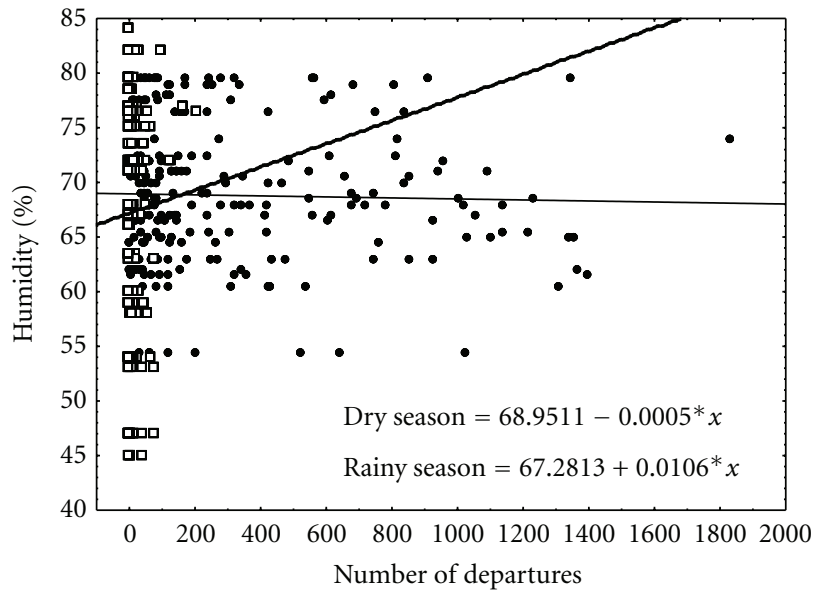

(b)

FIGURE 1: Relationship between temperature (a) and humidity (b) and the number of returning Melipona asilvai bees (• dry season; $\square$ rainy season).

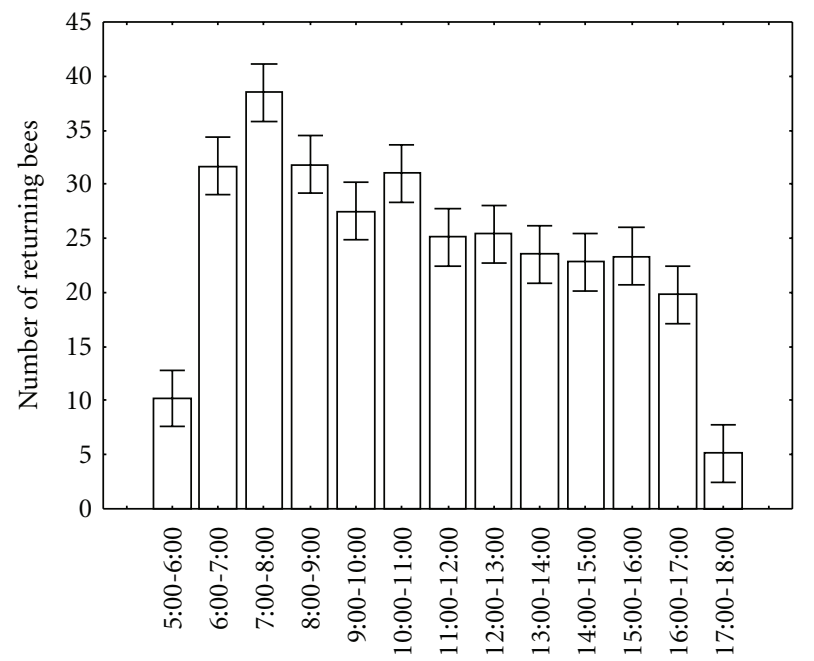

(a)

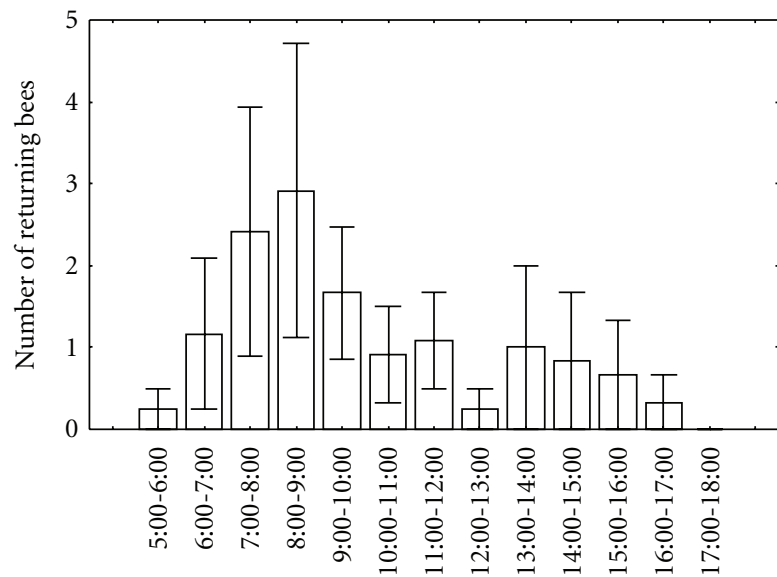

(b)

FIGURE 2: Daily frequency (mean \pm SE) of returning Melipona asilvai foragers during the 38 days of observations. (a) Dry season and (b) rainy season.

Mud collection was collected throughout the day and exhibited no specific peak activity (Figures 3(a) and 3(b)). This difference was significant for both periods of study (dry season: $H_{12}=86.19, P<0.001$; rainy season: $H_{12}=28.68$, $P=0.004) .16,106$ and 213 returning bees were observed with mud in both seasons, respectively.

3.3. Colony Productivity. The analyses of relative colony productivity showed that all parameters significantly varied between dry and rainy seasons (Figure 4). More nectar pots were observed during the rainy than the dry season (MannWhitney $U$ test $=9.10, P<0.001)$. On the contrary, the number of pollen pots was smaller during dry season (MannWhitney $U$ test $=5.15, P<0.001$ ). Brood production nearly suspended during the rainy season, so the number of cells being provisioned was significantly smaller in this season (Mann-Whitney $U$ test $=2.67, P<0.05$ ).

\section{Discussion}

4.1. Foraging Activities and Seasonality. Our results showed that during the 19 days of study in the rainy season, foraging departures of M. asilvai foragers for food resources (liquid and pollen) decreased over 20 times. Collection of resources seems not to be independently influenced by single factors such as temperature or humidity. Another factor that can also affect the foraging activity of stingless bees is the variation in the quantity and quality of food resources between days or seasons [10, 28]. Biesmeijer et al. [9] observed higher concentrations of sugar from nectar 


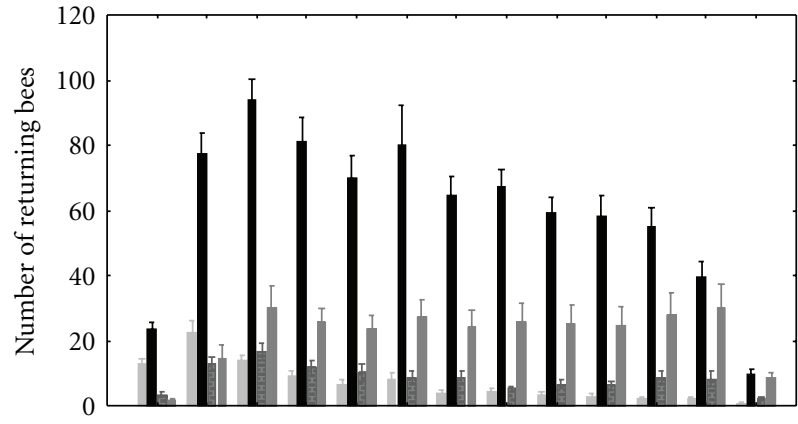

(a)

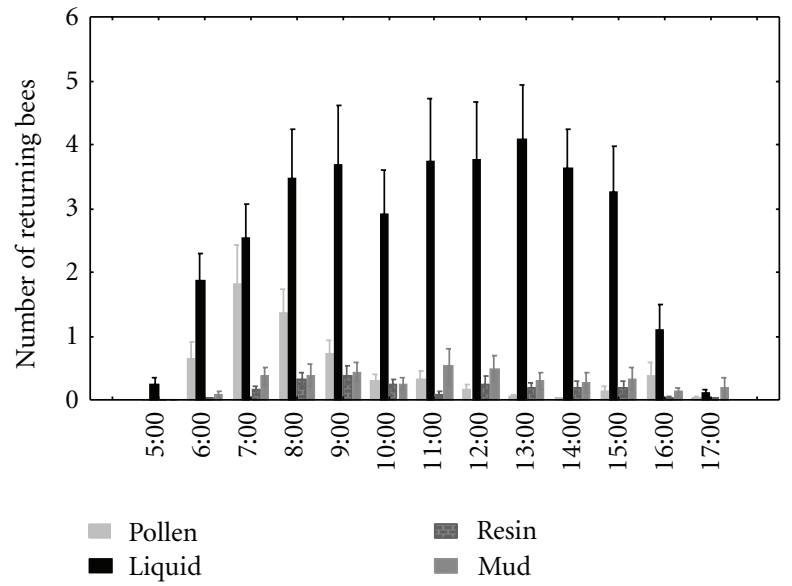

(b)

FIGURE 3: Daily frequency (mean \pm SD) of returning bees from three M. asilvai colonies bringing different types of loads during dry season (a) and rainy season (b).

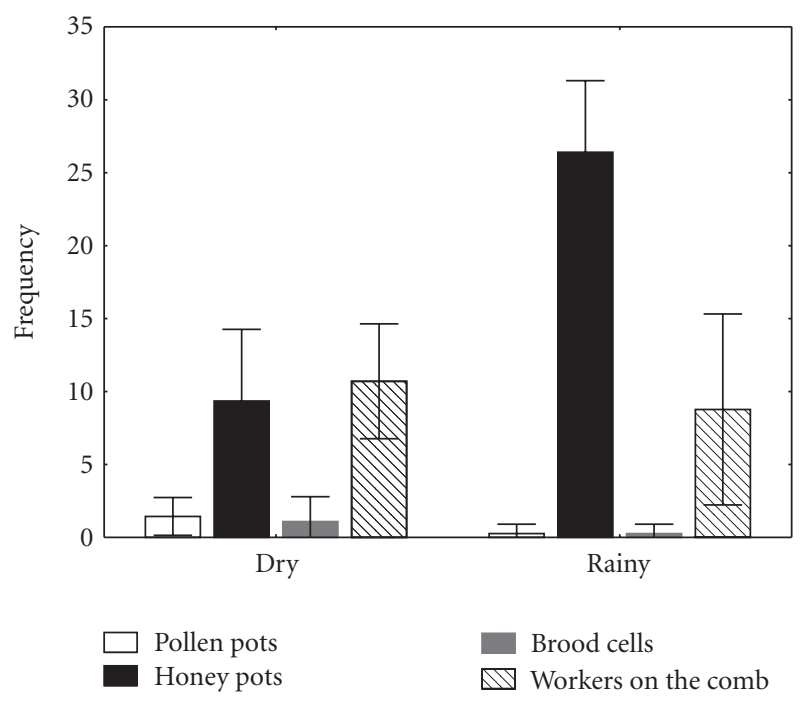

FIGURE 4: Colony productivity (mean \pm SD) patterns recorded during dry and rainy seasons.

collected by bees in dryer environments. Indeed, foraging organization is a result of individual foragers responding to environmental changes.

A previous study carried out with the same species in a drier area of Northeast Brazil registered a similar relationship between abiotic factors and foraging activities [29]. Other studies made in higher latitudes verified that temperature and relative humidity are the most limiting factors affecting the peaks of flight activity of stingless bees [17, 21, 23].

4.2. Foraging for Resources, Time of Day, and Season. Our studies showed that pollen collection in Melipona asilvai peaked during the first hours of the morning and decreased by the afternoon. This pattern has been seen in other Melipona species as well [30, 31]. Hilário et al. [21] observed that in M. bicolor bicolor an intense incoming of pollen took place in the early morning, when relative humidity was higher and temperature and light intensity were more moderate. Roubik [10] stated that pollen harvesting in the first hours of day coincides with a higher availability of this resource in the flowers.

Collection of liquids occurred throughout all activity periods in M. asilvai colonies. Although a $90 \%$ reduction of departures flights had been observed during the rainy season, there was a regular distribution of incoming liquid during the day in both seasons. Pierrot and Schilindwein [31] recorded higher rates of nectar foraging in the afternoon periods for M. scutellaris, which could be related to the gradual increase of sugar concentration in insolated flowers [32]. A similar pattern was found in an experiment carried out with $M$. rufiventris in southeast Brazil [24].

Collection of liquid was remarkable during the dry season (see Figure 3(a)). The number of bees returning with liquid loads was around $70 \%$ higher than other loads. These results, associated with both a decrease in flight activity and the number of honey pots registered in the rainy season, suggests that $M$. asilvai colonies experience a kind of seasonal diapause. In southern states where seasons are more defined, flight activity of $M$. bicolor schencki and M. marginata obscurior was more intense during summer and spring than autumn and winter $[33,34]$. Reproductive diapause has been observed in other southern species of stingless bees, such as Plebeia remota and $P$. droryana $[28,32]$.

4.3. Colony Productivity. Season had a significant effect on the relative parameters of colony production in M. asilvai. It is known that food resources are critical for the production of workers, queens, and males in stingless bees [35-37]. Although we did not record brood production in this study, it is reasonable to speculate that caste production and colony fission in this species occurs during the dry season when the rhythm of activities is higher. 


\section{Conclusion}

We conclude that the dry-rainy seasonal variation strongly affects external and internal biological parameters of Melipona asilvai. Foraging activities decrease by almost $90 \%$ from the dry to the rainy seasons, but temperature and humidity were not the main factors influencing departures. Honey storage and a sharp decline in activities during the rainy period suggest a seasonal diapause in this species.

\section{Acknowledgments}

This study is part of the M.S. Dissertation of Daniela L. do Nascimento as a requisite of the Post-Graduation Program in Ecology and Conservation (Universidade Federal de Sergipe). The authors thank Hans Kelstrup for his linguistic revision and two anonymous referees for the improvement on the paper. They also thank to Valdson Santos and M.S. José O. Dantas for helping with the management of the colonies and support during the experiments with M. asilvai. This study was supported by Fapitec and Capes to D. L. Nascimento and FAPESP (proc. 2010/10027-5) to F. S. Nascimento.

\section{References}

[1] J. C. Biesmeijer and M. C. W. Ermers, "Social foraging in stingless bees: how colonies of Melipona fasciata choose among nectar sources," Behavioral Ecology and Sociobiology, vol. 46, no. 2, pp. 129-140, 1999.

[2] J. C. Biesmeijer and H. de Vries, "Exploration and exploitation of food sources by social insect colonies: a revision of the scout-recruit concept," Behavioral Ecology and Sociobiology, vol. 49, no. 2-3, pp. 89-99, 2001.

[3] J. H. Fewell and S. M. Bertram, "Division of labor in a dynamic environment: response by honeybees (Apis mellifera) to graded changes in colony pollen stores," Behavioral Ecology and Sociobiology, vol. 46, no. 3, pp. 171-179, 1999.

[4] J. H. Fewell and R. E. Page Jr., "Colony-level selection effects on individual and colony foraging task performance in honeybees, Apis mellifera L.," Behavioral Ecology and Sociobiology, vol. 48, no. 3, pp. 173-181, 2000.

[5] D. M. Gordon, "The organization of work in social insect colonies," Nature, vol. 380, no. 6570, pp. 121-124, 1996.

[6] G. E. Robinson and R. E. Page Jr., "Genetic determination of nectar foraging, pollen foraging, and nest-site scouting in honey bee colonies," Behavioral Ecology and Sociobiology, vol. 24, no. 5, pp. 317-323, 1989.

[7] T. D. Seeley, The Wisdom of the Hive, Harvard University Press, Cambridge, Mass, USA, 1995.

[8] J. C. Biesmeijer, M. G. L. van Nieuwstadt, S. Lukács, and M. J. Sommeijer, "The role of internal and external information in foraging decisions of Melipona workers (Hymenoptera: Meliponinae)," Behavioral Ecology and Sociobiology, vol. 42, no. 2, pp. 107-116, 1998.

[9] J. C. Biesmeijer, M. Born, S. Lukács, and M. J. Sommeijer, "The response of the stingless bee Melipona beecheii to experimental pollen stress, worker loss and different levels of information input," Journal of Apicultural Research, vol. 38, no. 1-2, pp. 33-41, 1999.
[10] D. W. Roubik, Ecology and Natural History of Tropical Bees, Cambridge Tropical Biology Series, Cambridge University Press, Cambridge, UK, 1989.

[11] J. H. Fewell and M. L. Winston, "Colony state and regulation of pollen foraging in the honey bee, Apis mellifera L.," Behavioral Ecology and Sociobiology, vol. 30, no. 6, pp. 387-393, 1992.

[12] J. H. Fewell and M. L. Winston, "Regulation of nectar collection in relation to honey storage levels by honey bees, Apis mellifera," Behavioral Ecology, vol. 7, no. 3, pp. 286-291, 1996.

[13] J. C. Biesmeijer and E. J. Slaa, "Information flow and organization of stingless bee foraging," Apidologie, vol. 35, no. 2, pp. 143-157, 2004.

[14] A. Kleinert-Giovannini, "The influence of climatic factors on flight activity of Plebeia emerina Friese (Hymenoptera, Apidae, Meliponinae) in winter," Revista Brasileira de Entomologia, vol. 26, pp. 1-13, 1982.

[15] M. J. Sommeijer, G. A. de Rooy, W. Punt, and L. L. M. de Bruijn, "A comparative study of foraging behaviour and pollen resources of various stingless bees (Hymenoptera, Meliponinae) and honey bees (Hym., Apinae) in Trinidad, West-Indies," Apidologie, vol. 14, pp. 205-224, 1983.

[16] M. Ramalho, V. L. Imperatriz-Fonseca, A. KleinertGiovannini, and M. Cortopassi-Laurino, "Exploitation of floral resources by Plebeia remota (Holmberg) (Apidae, Meliponinae): floral preferences," Apidologie, vol. 16, pp. 307-329, 1985.

[17] A. Kleinert-Giovannini and V. L. Imperatriz-Fonseca, "Flight activity and responses to climatic conditions of two suspecies of Melipona marginata Lepeletier (Apidae, Meliponinae)," Journal of Apicultural Research, vol. 25, pp. 3-8, 1986.

[18] S. A. Corbet, M. Fussell, R. Ake et al., "Temperature and the pollinating activity of social bees," Ecological Entomology, vol. 18, no. 1, pp. 17-30, 1993.

[19] J. C. Biesmeijer, The organization of foraging in stingless bees of genus Melipona: an individual-oriented approach [Ph.D. thesis], Universität Utrecht, Utrecht, The Netherlands, 1997.

[20] L. L. M. de Bruijn and M. J. Sommeijer, "Colony foraging in different species of stingless bees (Apidae, Meliponinae) and the regulation of individual nectar foraging," Insectes Sociaux, vol. 44, no. 1, pp. 35-47, 1997.

[21] S. D. Hilário, V. L. Imperatriz-Fonseca, and A. de M. P. Kleinert, "Flight Activity and colony strength in the stingless bee Melipona bicolor bicolor (Apidae, Meliponinae)," Revista Brasileira de Biologia, vol. 60, pp. 299-306, 2000.

[22] C. Cortopassi-Laurino, "Seasonal strategies of harvesting by Melipona sp. in the Amazon region," in Proceedings of the 8th IBRA International Conference on Tropical Bees and VI Encontro Sobre Abelhas, pp. 258-263, Ribeirão Preto, Brazil, 2004.

[23] A. O. Fidalgo and A. M. P. Kleinert, "Foraging behavior of Melipona rufiventris Lepeletier (Apinae; Meliponini) in Ubatuba, SP, Brazil," Brazilian Journal of Biology, vol. 67, no. 1, pp. 133-140, 2007.

[24] A. O. Fidalgo and A. M. P. Kleinert, "Floral preferences and climate influence in nectar and pollen foraging by melipona rufiventris lepeletier (Hymenoptera: Meliponini) in Ubatuba, São Paulo State, Brazil," Neotropical Entomology, vol. 39, no. 6, pp. 879-884, 2010.

[25] S. D. Hilário and V. L. Imperatriz-Fonseca, "Pollen foraging in colonies of Melipona bicolor (Apidae, Meliponini): effects of season, colony size and queen number," Genetics and Molecular Research, vol. 8, no. 2, pp. 664-671, 2009. 
[26] S.G. Amâncio, Influência da evolução costeira holocênica na ocupação da costa do estado de Sergipe por Grupos Sambaquieiros [Dissertation], IGEO/UFBA, Salvador, Brazil, 2001.

[27] J. Neter, M. H. Kutner, C. J. Nachtsheim, and W. Wasserman, Applied Linear Statistical Models, Irwin, Chicago, Il, USA, 1996.

[28] P. Nunes-Silva, S. D. Hilário, S. F. Pérsio de Souza, and V. L. Imperatriz-Fonseca, "Foraging activity in Plebeia remota, a stingless bee species, is influenced by the reproductive state of a colony," Psyche, vol. 1, pp. 1-17, 2010.

[29] B. A. Souza, C. A. L. Carvalho, and R. M. O. Alves, "Flight activity of Melipona asilvai moure (Hymenoptera: Apidae)," Brazilian Journal of Biology, vol. 66, no. 2B, pp. 731-737, 2006.

[30] D. W. Roubik and S. L. Buchmann, "Nectar selection by Melipona and Apis mellifera (Hymenoptera: Apidae) and the ecology of nectar intake by bee colonies in a tropical forest," Oecologia, vol. 61, no. 1, pp. 1-10, 1984.

[31] L. M. Pierrot and C. Schlindwein, "Variation in daily flight activity and foraging patterns in colonies of uruçu-Melipona scutellaris Latreille (Apidae, Meliponini)," Revista Brasileira de Zoologia, vol. 20, pp. 565-571, 2003.

[32] Y. Terada, C. A. Garófalo, and S. F. Sakagami, "Age-survival curves for workers of two eusocial bees (Apis mellifera and Plebeia droryana) in a subtropical climate, with notes on worker polyethism in P. droryana," Journal of Apicultural Research, vol. 14, pp. 161-170, 1975.

[33] N. T. Ferreira Junior, B. Blochtein, and J. F. de Moraes, "Seasonal flight and resource collection patterns of colonies of the stingless bee Melipona bicolor schencki Gribodo (Apidae, Meliponini) in an Araucaria forest area in southern Brazil," Revista Brasileira de Entomologia, vol. 54, no. 4, pp. 630-636, 2010.

[34] F. V. B. Borges and B. Blochtein, "Atividades externas de Melipona marginata obscurior Moure (Hymenoptera, Apidae), em distintas épocas do ano, em São Francisco de Paula, Rio Grande do Sul, Brasil," Revista Brasileira Zoologia, vol. 22, pp. 680-686, 2005.

[35] W. E. Kerr and R. A. Nielsen, "Evidences that genetically determined Melipona queens can become workers," Genetics, vol. 54, no. 3, pp. 859-866, 1966.

[36] H. Moo-Valle, J. J. G. Quezada-Euán, and T. Wenseleers, “The effect of food reserves on the production of sexual offspring in the stingless bee Melipona beecheii (Apidae, Meliponini)," Insectes Sociaux, vol. 48, no. 4, pp. 398-403, 2001.

[37] M. M. Morais, F. S. Nascimento, R. A. Pereira, and L. R. Bego, "Colony internal conditions related to caste production in Melipona compressipes fasciculata (Apidae, Meliponini)," Insectes Sociaux, vol. 53, no. 3, pp. 265-268, 2006. 

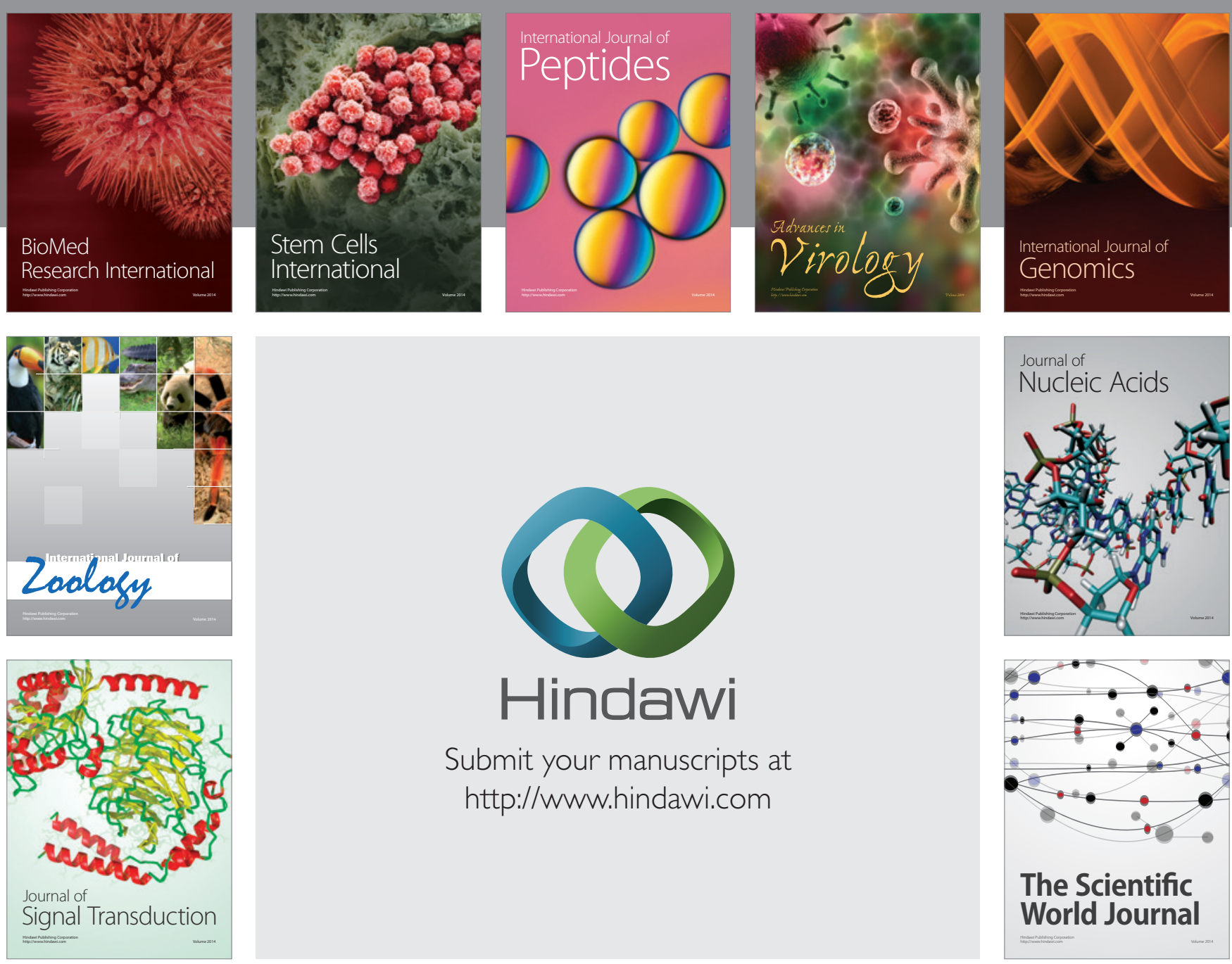

Submit your manuscripts at

http://www.hindawi.com
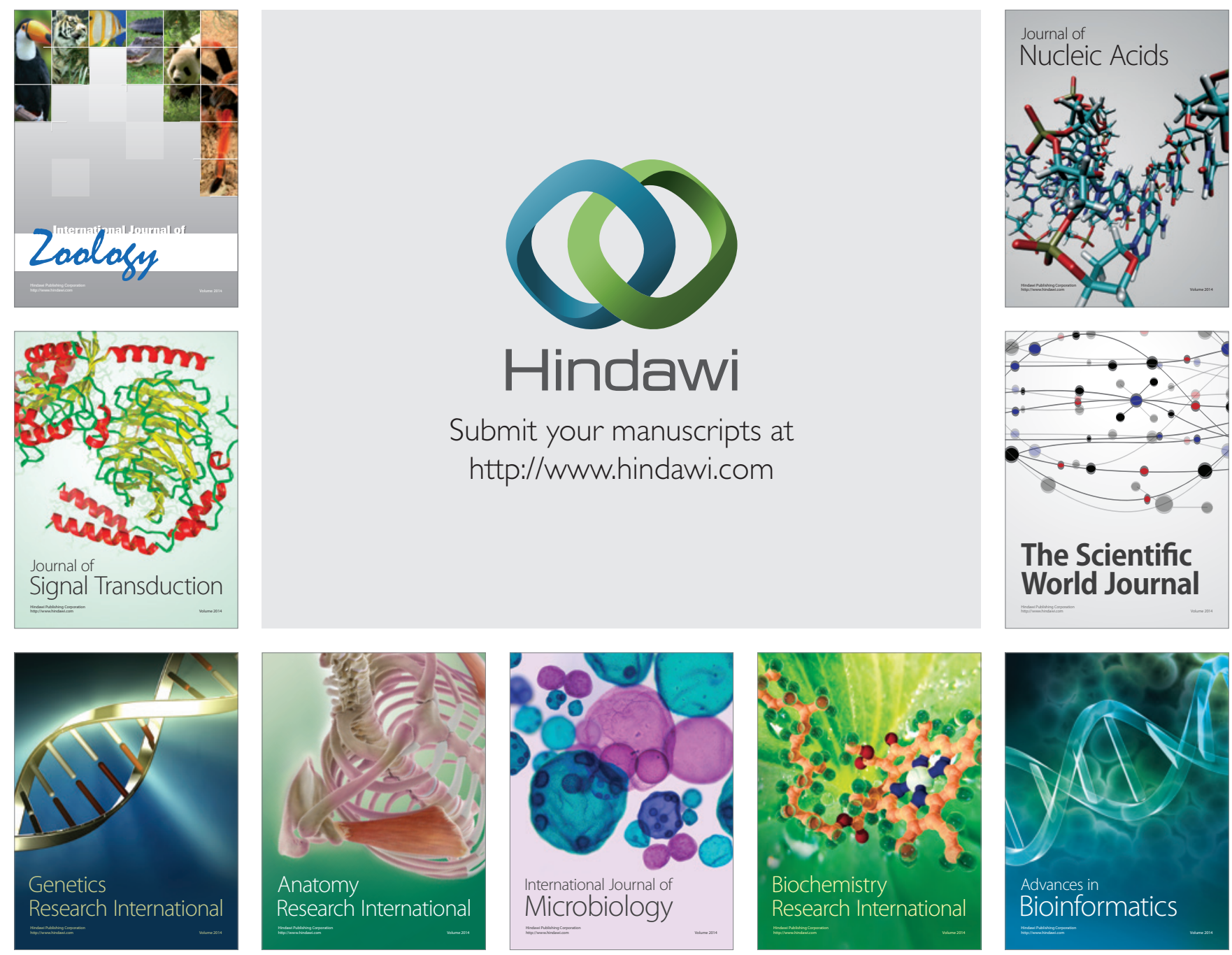

The Scientific World Journal
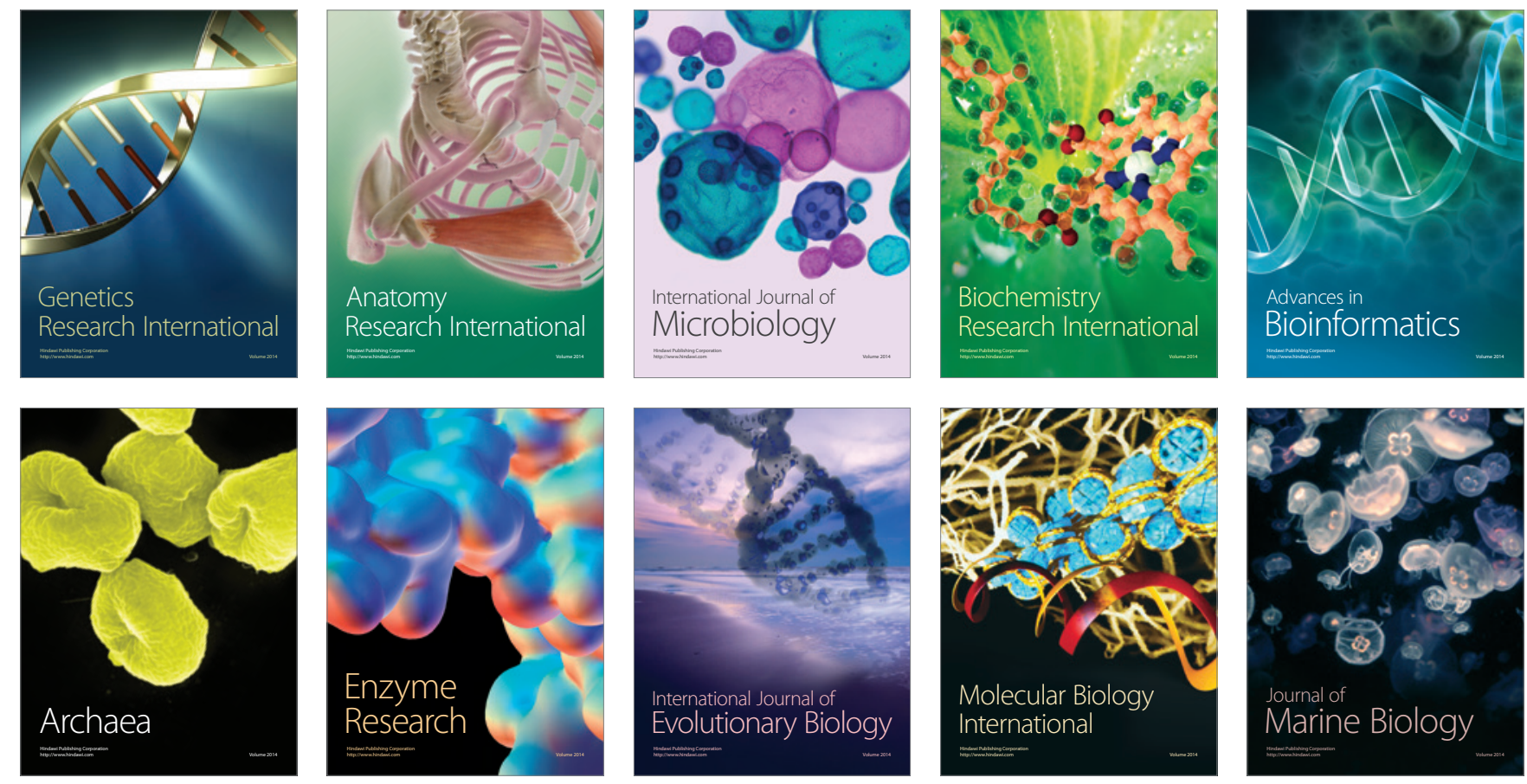